\title{
DL-Methionine supplementation in a low-fishmeal diet affects the TOR/S6K pathway by stimulating ASCT2 amino acid transporter and insulin-like growth factor-I in the dorsal muscle of juvenile cobia (Rachycentron canadum)
}

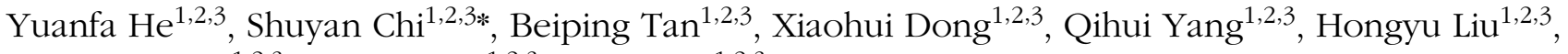 \\ Shuang Zhang ${ }^{1,2,3}$, Fenglu Han ${ }^{1,2,3}$ and Di Liu ${ }^{1,2,3}$ \\ ${ }^{1}$ Laboratory of Aquatic Animal Nutrition and Feed, Fisheries College, Guangdong Ocean University, Zhanjiang 524088, \\ People's Republic of China \\ ${ }^{2}$ Aquatic Animals Precision Nutrition and High-Efficiency Feed Engineering Research Center of Guangdong Province, \\ Zhanjiang 524088, People's Republic of China \\ ${ }^{3}$ Key Laboratory of Aquatic, Livestock and Poultry Feed Science and Technology in South China, Ministry of Agriculture, \\ Zhanjiang 524088, People's Republic of China \\ (Submitted 20 January 2019 - Final revision received 21 June 2019 - Accepted 28 June 2019)
}

Abstract

An 8-week feeding experiment was conducted to investigate the effects of DL-methionine (Met) supplementation in a low-fishmeal diet on growth, key gene expressions of amino acid transporters and target of rapamycin (TOR) pathway in juvenile cobia, Rachycentron canadum. Seven isonitrogenous and isolipidic diets were formulated, containing $0 \cdot 72,0 \cdot 90,1 \cdot 00,1 \cdot 24,1.41,1.63$ and $1.86 \%$ Met. Weight gain and specific growth rates increased gradually with Met levels of up to $1.24 \%$ and then decreased gradually. In dorsal muscle, mRNA levels of ASCT2 in the $1.00 \%$ Met group were significantly up-regulated compared with $0.72,1.63$, and $1.86 \%$. The insulin-like growth factor-I (IGF-I) mRNA levels in the dorsal muscle of fish fed 1.00 and 1.24\% Met were higher than those in fish fed other Met levels. In addition, fish fed 1.24\% Met showed the highest mRNA levels of TOR and phosphorylation of TOR on $\mathrm{Ser}^{2448}$. The phosphorylation of ribosomal p70-S6 kinase (S6K) on Ser ${ }^{371}$ in the dorsal muscle of fish fed $1.86 \%$ Met was higher than those in the $0.72 \%$ group. In conclusion, straight broken-line analysis of weight gain rate against dietary Met level indicates that the optimal Met requirement for juvenile cobia is $1 \cdot 24 \%$ (of DM, or $2 \cdot 71 \%$ dietary protein). Met supplementation in a low-fishmeal diet increased cobia growth via a mechanism that can partly be attributed to Met's ability to affect the TOR/S6K signalling pathway by enhancing ASCT2 and IGF-I transcription in cobia dorsal muscle.

Key words: Rachycentron canadum: Methionine: Serum hormones: Amino acid transporters: TOR/S6K pathway

Generally, protein is the most abundant nutrient in fish feed ${ }^{(1)}$ and is the most crucial nutrient for keeping fish in healthy condition. Fishmeal is considered the most nutritious and digestible feed for farmed fish. However, as the feed demand increases, the amount of fishmeal used in aquaculture compound feeds decreases to offset its high $\operatorname{cost}^{(2)}$. It is worth noting that the substitution of different protein resources for fishmeal usually results in a deficient supply of essential amino acids (AA). Supplementation with exogenous AA can constitute the 'key components of cost-effective fish feed formulations ${ }^{\text {(3) }}$. In view of sustainable fish nutrition, more knowledge concerning the protein and crystalline AA utilisation efficiency of fish feeds are indispensable. Methionine (Met) is the first limiting AA in common plant protein sources, such as soyabean meal, peanut meal and copra meal ${ }^{(4)}$. Therefore, supplementation with exogenous Met is particularly important to avoid disturbances to protein metabolism and reduce nitrogen losses in farmed fish $^{(5-7)}$.

Free AA derived from the diet or protein degradation are efficiently absorbed by epithelial cells along the digestive tract through specific transporters ${ }^{(8)}$, which facilitate cellular AA supply and homeostasis ${ }^{(9)}$. The sites of Met absorption in the fish intestine differ according to the species. The highest uptake occurs in the foregut area, though Met absorption occurs throughout the intestine of the Nile tilapia, Oreochromis niloticus ${ }^{(10)}$. However, Met absorption in the green sturgeon, Acipenser medirostris, occurs

Abbreviations: 4E-BP, 4E-binding protein; AA, amino acid; GH, growth hormone; GLU, glucose; IGF-I, insulin-like growth factor-I; INS, insulin; S6K, S6 kinase; TOR, target of rapamycin; WGR, weight gain rate.

* Corresponding author: S. Chi, email chishuyan77@163.com 
mainly in the midgut and hindgut ${ }^{(11)}$. The Met transport mechanism relies mainly on a high-affinity transport system in gilthead bream, Sparus aurata, and is obligatorily dependent on the presence of $\mathrm{Na}^{+}$and $\mathrm{Cl}^{-(12)}$. System $\mathrm{B}^{0}$ and AlaSerCys (ASC)-like $\mathrm{Na}^{+}$dependent neutral AA transporters have been reported to improve the absorption of Met in human intestinal epithelial cells $(\mathrm{CacO}-2)^{(13)}$, in the brush-border membrane vesicles of the chicken jejunum $^{(14)}$ and in shrimp hepatopancreatic cells ${ }^{(15)}$. ASCT2 (SLC1A5) and $\mathrm{B}^{0} \mathrm{AT} 1$ (SLC6A19) were expressed in all examined mammal tissues and were located in the brush borders of epithelial cells where they mediated the transportation of neutral $\mathrm{AA}^{(16-18)}$. The former is an $\mathrm{Na}^{+}$- and $\mathrm{Cl}^{-}$-dependent transporter, which actively transports most neutral AA except for aromatic ones, and is mainly expressed in the kidney and intestine. The latter is an $\mathrm{Na}^{+}$-dependent, $\mathrm{Cl}^{-}$-independent and $\mathrm{pH}$-sensitive transporter, with the highest transport efficiency for leucine, isoleucine, Met and valine ${ }^{(19)}$. However, little information about ASCT2 and $\mathrm{B}^{0} \mathrm{AT} 1$ is available for marine fish. Previous studies have provided the gene expression profiles and dietary regulation of these two transporters in turbot, Scophthalmus maximus L. ${ }^{(20,21)}$.

AA transporters act not only as carriers but also as sensors to detect AA concentrations and/or cell growth factor, so as to activate an intra-cellular target of the rapamycin (TOR) pathway ${ }^{(22-24)}$. Met can significantly affect the secretion of the growth hormone (GH)-insulin-like growth factor-I (IGF-I) axis and the regulation of protein metabolism in rainbow trout, Oncorbynchus mykiss ${ }^{(25,26)}$. IGF-I binding with its receptor in the cell membrane can activate the TOR protein via the phosphoinositide 3-kinase (PI3K)/protein kinase $\mathrm{B}$ (Akt) pathway. TOR modulates the activity of two important translation regulators, ribosomal p70-S6 kinase (S6K) and $4 \mathrm{E}-$ binding protein $(4 \mathrm{E}-\mathrm{BP})$, to affect protein synthesis in animals ${ }^{(27)}$. Met, as a signal molecule involved in the modulation of both IGF-I and AA transporter mRNA expression ${ }^{(28-30)}$, regulates the TOR signalling pathway and influences muscle protein synthesis in fish such as rainbow trout ${ }^{(25,31)}$ and turbot $^{(32)}$

An economically important carnivorous marine fish, cobia, is globally distributed. It supports recreational and commercial fisheries in the Gulf of Mexico and US Atlantic Ocean and has been widely reared in southern China ${ }^{(33-35)}$. Although the dietary Met requirements of cobia have been reported ${ }^{(35,36)}$, no information is available on how an optimal Met diet affects growth, regulates key AA transporter genes and affects protein metabolism. Therefore, this research aims to determine the mechanism by which dietary Met influences the growth of juvenile cobia via the TOR signalling pathway.

\section{Materials and methods \\ Experimental design}

Seven isonitrogenous and isolipidic diets were formulated, containing $0.72,0.90,1.00,1.24,1.41,1.63$ and $1.86 \%$ Met (Table 1). L-Aspartic acid and glycine were used to substitute for Met in the low-Met diets. Ingredients were ground, weighed and then well mixed with fish oil, soya oil, and soya lecithin. After mixing, water was added to produce a mash suitable for extrusion. The diets were sieved into the 2-mm-diameter pellet size and then air-dried at room temperature until the moisture was reduced to approximately $10 \%$. The pellets were packaged in Ziploc bags and stored at $-20^{\circ} \mathrm{C}$ until use. The AA concentrations of the diets were measured by an automatic AA analyser (A300; MembraPure). The AA composition of each diet is presented in Table 2 .

\section{Fish rearing}

Cobia were bought from a commercial hatchery in Wenchang, China. All fish were fed with commercial feed and acclimated to the experimental conditions for $7 \mathrm{~d}$. At the initiation of the feeding trial, fish were fasted for $24 \mathrm{~h}$. Healthy cobia (mean initial weight 9.79 (sE 0.04) g) were randomly assigned into seven groups in triplicate with forty individuals per sea cage $(1.0 \times 1.0 \times 2.0 \mathrm{~m})$. The fish were slowly and evenly fed by hand to apparent satiation twice daily at 07.00 and 18.00 hours. Throughout the feeding trial the water temperature fluctuated from 28 to $30^{\circ} \mathrm{C}$, the dissolved oxygen concentration was $>7.0 \mathrm{mg} / \mathrm{l}$ and the salinity was $24-26 \mathrm{~g} / \mathrm{l}$.

\section{Sample collection}

At the end of 8th week, $24 \mathrm{~h}$ after the last feed, the fish in each cage were counted and weighed. Fish were anaesthetised with benzocaine $(30 \mathrm{mg} / \mathrm{l})$. Three fish from each tank were randomly selected and their blood samples were drawn from the caudal vein with a $1-\mathrm{mL}$ syringe. Blood samples were centrifuged $\left(3000 \mathrm{~g}\right.$ for $10 \mathrm{~min}$ ) at $4^{\circ} \mathrm{C}$ and the serum was separated and stored at $-80^{\circ} \mathrm{C}$ for later serum hormone level and glucose (GLU) analyses. The intestinal tract, liver and dorsal muscle of three fish from each cage were sampled and pooled in a centrifuge tube with RNAlater ${ }^{\circledR}$ solution (Ambion) and frozen at $-80^{\circ} \mathrm{C}$ until analysis of gene expression. The dorsal muscle was dissected, immediately frozen in liquid $\mathrm{N}_{2}$ and stored in a freezer at $-80^{\circ} \mathrm{C}$ prior to protein expression analysis.

\section{Serum hormone and glucose concentration}

Serum insulin (INS) levels were measured by time-resolved fluoroimmunoassay, according to Andoh ${ }^{(37)}$. This assay uses antibarfin flounder insulin-II antiserum and B1 monobiotinylated barfin flounder insulin-I, which were synthesised chemically (Peptide Institute). Insulin-I of known concentrations was used as a standard. The cross-reactivities of insulin-I and -II were identical in this time-resolved fluoroimmunoassay ${ }^{(37)}$. No significant cross-reactivity was observed in the fractions collected during reversed-phase chromatography of the serum, except for those containing INS, suggesting that the antiserum does not recognise preproinsulin, proinsulin, or their intermediates. The inter- and intra-assay CV were 7.0 and $7.6 \%$, respectively. Samples were measured in duplicate.

Serum GH levels were measured using ${ }^{125}$ I-labelled recombinant salmon GH (rsGH: lot no. DAB-GHB1; GroPep) for labelled samples, unlabelled rsGH as a standard and anti-salmon $\mathrm{GH}$ 
Table 1. Composition and nutrient levels of experimental diets (\% DM)

\begin{tabular}{|c|c|c|c|c|c|c|c|}
\hline & \multicolumn{7}{|c|}{ Dietary Met levels (\%) } \\
\hline & 0.72 & 0.90 & 1.00 & $1 \cdot 24$ & 1.41 & 1.63 & $1 \cdot 86$ \\
\hline \multicolumn{8}{|l|}{ Ingredients } \\
\hline Brown fish meal & 20.00 & $20 \cdot 00$ & 20.00 & $20 \cdot 00$ & 20.00 & $20 \cdot 00$ & $20 \cdot 00$ \\
\hline Dehulled soyabean meal & 21.00 & 21.00 & 21.00 & 21.00 & 21.00 & 21.00 & 21.00 \\
\hline Maize gluten meal & 5.00 & 5.00 & 5.00 & 5.00 & 5.00 & $5 \cdot 00$ & $5 \cdot 00$ \\
\hline Wheat gluten flour & 5.00 & 5.00 & 5.00 & 5.00 & $5 \cdot 00$ & 5.00 & 5.00 \\
\hline Wheat flour & $26 \cdot 00$ & $26 \cdot 00$ & $26 \cdot 00$ & $26 \cdot 00$ & $26 \cdot 00$ & $26 \cdot 00$ & $26 \cdot 00$ \\
\hline Amino acid mixture* & $6 \cdot 18$ & $6 \cdot 18$ & $6 \cdot 18$ & $6 \cdot 18$ & $6 \cdot 18$ & $6 \cdot 18$ & $6 \cdot 18$ \\
\hline DL-Met & 0.00 & 0.20 & 0.40 & 0.60 & 0.80 & 1.00 & 1.20 \\
\hline Asp+Gly (1:1) & $1 \cdot 20$ & 1.00 & 0.80 & 0.60 & 0.40 & 0.20 & 0.00 \\
\hline Fish oil & 4.00 & 4.00 & 4.00 & 4.00 & 4.00 & 4.00 & 4.00 \\
\hline Soya oil & 3.00 & 3.00 & 3.00 & 3.00 & 3.00 & 3.00 & 3.00 \\
\hline Soya lecithin & $2 \cdot 00$ & 2.00 & $2 \cdot 00$ & $2 \cdot 00$ & $2 \cdot 00$ & 2.00 & $2 \cdot 00$ \\
\hline Vitamin premix $\dagger$ & 0.20 & 0.20 & 0.20 & 0.20 & 0.20 & 0.20 & 0.20 \\
\hline Mineral premix $\ddagger$ & 0.20 & 0.20 & 0.20 & 0.20 & 0.20 & 0.20 & 0.20 \\
\hline Others§ & $6 \cdot 22$ & $6 \cdot 22$ & $6 \cdot 22$ & $6 \cdot 22$ & $6 \cdot 22$ & $6 \cdot 22$ & $6 \cdot 22$ \\
\hline Total & $100 \cdot 00$ & $100 \cdot 00$ & $100 \cdot 00$ & $100 \cdot 00$ & $100 \cdot 00$ & $100 \cdot 00$ & $100 \cdot 00$ \\
\hline \multicolumn{8}{|l|}{ Nutrient levels } \\
\hline DL-Met & 0.72 & 0.90 & 1.00 & 1.24 & 1.41 & 1.63 & 1.86 \\
\hline Cystine & 0.47 & 0.44 & 0.44 & 0.47 & 0.48 & 0.47 & 0.41 \\
\hline Crude protein & $46 \cdot 14$ & $46 \cdot 13$ & 46.06 & $46 \cdot 82$ & $46 \cdot 48$ & $46 \cdot 89$ & $46 \cdot 07$ \\
\hline Crude lipid & 11.41 & $11 \cdot 18$ & 11.34 & 11.06 & $11 \cdot 25$ & $11 \cdot 22$ & 11.48 \\
\hline Ash & 7.33 & 7.51 & 7.55 & 7.51 & 7.52 & $7 \cdot 52$ & 7.50 \\
\hline Moisture & 7.04 & $7 \cdot 10$ & 7.03 & $7 \cdot 13$ & 7.68 & $7 \cdot 18$ & $7 \cdot 21$ \\
\hline
\end{tabular}

Met, methionine; Asp, aspartic acid; Gly, glycine.

*Amino acid mixture (per $100 \mathrm{~g}$ diet): L-lysine, $0.320 \mathrm{~g}$; L-histidine, $0.381 \mathrm{~g}$; leucine, $1.041 \mathrm{~g}$; L-isoleucine, $0.303 \mathrm{~g}$; L-phenylalanine, $0.854 \mathrm{~g}$; L-valine, $0.857 \mathrm{~g}$; L-aspartic acid, $1.21 \mathrm{~g}$; glycine, $1.21 \mathrm{~g}$. Amino acids obtained from Shanghai Sanjie Biochemical Technology Co., Ltd.

$†$ Vitamin premix was obtained from Qingdao Master Biotechnology Co., Ltd.

‡ Mineral premix was obtained from Qingdao Master Biotechnology Co., Ltd.

$\S$ Others: microcrystalline cellulose $3.72 \%$; vitamin C, $0.35 \%$; choline chloride, $0.50 \% ; \mathrm{Ca}_{2}\left(\mathrm{H}_{2} \mathrm{PO}_{4}\right)_{2}, 1.50 \%$; antioxidant, $0.05 \%$; attractant, $0.1 \%$.

Table 2. Amino acid composition of the test ingredients used in the experiment (\% DM)

\begin{tabular}{|c|c|c|c|c|c|c|c|}
\hline \multirow[b]{2}{*}{ Amino acids } & \multicolumn{7}{|c|}{ Dietary Met levels (\%) } \\
\hline & 0.72 & 0.90 & 1.00 & 1.24 & 1.41 & 1.63 & 1.8 \\
\hline \multicolumn{8}{|c|}{ Essential amino acids } \\
\hline Met & 0.72 & 0.90 & 1.00 & 1.24 & 1.41 & 1.63 & \\
\hline Valine & 2.40 & 2.39 & $2 \cdot 30$ & $2 \cdot 24$ & 2.38 & 2.46 & \\
\hline Isole & 2.08 & $2 \cdot 04$ & $2 \cdot 11$ & 1.94 & 1.91 & .96 & \\
\hline Phe & $2 \cdot 80$ & & $2 \cdot 77$ & 2.5 & & & \\
\hline Leuc & 4.09 & 3.92 & 3.9 & 3.85 & 3.91 & & \\
\hline Thre & 1.47 & 1.50 & 1.50 & 1.58 & 1.46 & 0 & \\
\hline Lysir & 2.51 & 2.45 & $2 \cdot 47$ & 2.63 & $2 \cdot 49$ & 2.54 & \\
\hline Histi & 1.47 & 1.49 & 1.49 & 1.49 & 1.51 & 1.51 & \\
\hline & & & 2.08 & $2 \cdot 23$ & & 2.04 & \\
\hline Tryptophan* & ND & ND & ND & ND & ND & ND & \\
\hline \multicolumn{8}{|c|}{ Non-essential amino acids } \\
\hline Tyrosine & 1.37 & 1.33 & 1.34 & 1.37 & 1.40 & 1.42 & \\
\hline Alanine & 2.03 & 2.07 & $2 \cdot 04$ & $2 \cdot 25$ & 2.05 & $2 \cdot 16$ & \\
\hline & 2.40 & $2 \cdot 36$ & $2 \cdot 3$ & $2 \cdot 34$ & $2 \cdot 41$ & 2.5 & \\
\hline & $5 \cdot 2$ & 4.9 & $5 \cdot 2$ & $5 \cdot 37$ & 5.41 & $5 \cdot 5$ & \\
\hline Serir & 1.78 & 1.83 & 1.81 & 1.74 & 1.72 & 1.62 & \\
\hline Cystir & 0.47 & 0.44 & 0.44 & 0.47 & 0.48 & 0.47 & \\
\hline Aspartic acid & 4.97 & 4.99 & 4.92 & 4.44 & $4 \cdot 81$ & 4.65 & \\
\hline Proline & 2.58 & $2 \cdot 68$ & 2.65 & $2 \cdot 35$ & 2.60 & $2 \cdot 78$ & \\
\hline Amino acid sum & 40.50 & $40 \cdot 26$ & 40.43 & $40 \cdot 07$ & $40 \cdot 76$ & 41.01 & 41.4 \\
\hline
\end{tabular}

Met, methionine; ND, not determined.

*Tryptophan was not determined.

primary antibody (lot no. AJI-PAN1; GroPep), as previously described $^{(38)}$. The inter- and intra-assay $\mathrm{CV}$ were 7.0 and $7 \cdot 6 \%$, respectively. Samples were measured in duplicate.
Serum IGF-I levels were measured by time-resolved fluoroimmunoassay using anti-barramundi IGF-I anti-serum (GroPep) and flounder ${ }^{125}$ I-IGF-I as the labelled ligand ${ }^{(39)}$. Flounder IGF-I was also purchased from GroPep and used at known concentration as a standard. The inter- and intra-assay CV were 5.0 and $6.0 \%$, respectively. Samples were measured in duplicate.

Serum GLU concentrations were measured by a fully automatic biochemical analyser (Hitachi) with the matching commercial reagent kit (Nanjing Whitman Biotech Co., Ltd.). Samples were measured in duplicate.

\section{RNA extraction and quantitative $P C R$ analysis}

The total RNA of the intestinal tract, liver and dorsal muscle of cobia were extracted using Trizol Reagent (Takara). The integrity of the total RNA sample was tested by electrophoresing on a $1.2 \%$ denaturing agarose gel, while the purity and concentration were determined by a Nano Drop ${ }^{\circledR}$ ND-2000 spectrophotometer. The absorption ratios (260:280 nm) for all the samples were approximately $2 \cdot 00$. Subsequently, $1 \mu \mathrm{g}$ of the total RNA was reverse-transcribed into complementary DNA (cDNA) using the Prime Script $^{\mathrm{TM}}$ RT reagent kit with genomic DNA Eraser (Takara), according to the manufacturers' instructions. Primers were then designed using Primer 5 software. All primer sequences used in the present study are listed in Table 3. Targeted gene expression levels were determined using a quantitative real-time PCR detection system (ABI 7500; Applied Biosystems) using a SYBR ${ }^{\circledR}$ Premix Ex Taq $^{\mathrm{TM}}$ system. The thermal cycle program 
Table 3. Nucleotide sequence of primers for real-time quantitative PCR amplification

\begin{tabular}{|c|c|c|c|}
\hline Genes & Primer sequence $\left(5^{\prime}-3^{\prime}\right)$ & Product size (bp) & GenBank ID \\
\hline ASCT2 & $\begin{array}{l}\text { Forward: TGCTGAATGTAGAGGGCG } \\
\text { Reverse: TCAATGAGTGGCGAGTGC }\end{array}$ & 151 & KR092192 \\
\hline $\mathrm{B}^{0} \mathrm{AT} 1$ & $\begin{array}{l}\text { Forward: CCGAAATGGGACAACAAAG } \\
\text { Reverse: GAACCAGCAGGATCAGGAA }\end{array}$ & 142 & KR092193 \\
\hline Insulin-like growth factor-I & $\begin{array}{l}\text { Forward: CСАСАСССТСТСАСТАСТGСТ } \\
\text { Reverse: ССТСТСТСТССАСАСАСАААСТ }\end{array}$ & 123 & KF751872 \\
\hline Target of rapamycin & $\begin{array}{l}\text { Forward: AAGTACATGCGCTCTGGAAACG } \\
\text { Reverse: GGATGCGGATGATAGGCTGG }\end{array}$ & 149 & Luo et al. ${ }^{(40)}$ \\
\hline$\beta$-Actin & $\begin{array}{l}\text { Forward: TGCGTGACATCAAGGAGAAGC } \\
\text { Reverse: TACCGAGGAAGGAAGGCTGG }\end{array}$ & 180 & Luo et al. ${ }^{(40)}$ \\
\hline
\end{tabular}

was as follows: initial denaturation at $95^{\circ} \mathrm{C}$ for $2 \mathrm{~min}$ followed by forty cycles of $95^{\circ} \mathrm{C}$ for $10 \mathrm{~s}, 59^{\circ} \mathrm{C}$ for $10 \mathrm{~s}$ and $72^{\circ} \mathrm{C}$ for $20 \mathrm{~s}$. At the end of each reaction, a melting curve analysis was performed to confirm the specificity of production. In addition, the amplification efficiency of the primers was analysed according to the equation $E=10^{(-1 / \text { slope })}-1$. The amplification efficiencies ranged between 0.92 and 1.05. To calculate relative expression levels, the comparative cycle threshold (CT) method ( $2^{-\Delta \Delta \mathrm{Ct}}$ method) was used, as described by Yao et al. ${ }^{(41)}$.

\section{Protein extraction and Western blot analysis}

Dorsal muscles (approximately $40 \mathrm{mg}$ ) were homogenised with Bioprep-24 Homogeniser (Allsheng) on ice and lysed in Enhanced RIPA Lysis Buffer (50-mm Tris, 150-mm NaCl, $1 \%$ Triton X-100, 0.1\% SDS, 1-mm EDTA, pH 7.4; Biosharp Biotech) with a protease and phosphatase inhibitor cocktail (Thermo Fisher Scientific). Lysates were centrifuged at $12000 \mathrm{~g}$ for $20 \mathrm{~min}$ at $4^{\circ} \mathrm{C}$. Protein concentrations were determined using a BCA Protein Assay kit (Thermo Fisher Scientific) with bovine serum albumin as a standard. Lysates ( $30 \mu \mathrm{g}$ of total protein) were separated by SDS-PAGE and transferred to $0 \cdot 45-\mu \mathrm{m}$ polyvinylidene difluoride membranes (Millipore) for Western blot analysis. Proteins were blocked with $5 \%$ non-fat dry milk for $1 \mathrm{~h}$ at room temperature. Appropriate primary antibodies were purchased from Cell Signaling Technology Inc.: phosphor-TOR (Ser ${ }^{2448}$; rabbit no. 2971), TOR (rabbit no. 2972), phospho-p70-S6K (Ser ${ }^{371}$; rabbit no. 9208), p70-S6K (rabbit no. 9202), phospho$4 \mathrm{E}-\mathrm{BP} 1\left(\mathrm{Thr}^{37 / 46}\right.$; rabbit no. 9459) and 4E-BP1 (rabbit no. 9452). Antibody for glyceraldehyde-3-phosphate dehydrogenase was from Hangzhou Goodhere Biotechnology. Since mammalian antibodies were used, AA sequences of the studied cobia proteins were aligned in the NCBI database (https://blast.ncbi.nlm.nih.gov/Blast.cgi) to check the identity of the antibodies. In previous studies, all antigenic regions of these antibodies have been successfully used in turbot ${ }^{(42)}$, rainbow trout ${ }^{(43)}$ and zebrafish ${ }^{(44)}$. Then membranes were incubated with horseradish peroxidase (HRP)-labelled goat anti-rabbit $\operatorname{IgG}(\mathrm{H}+\mathrm{L})$ second antibody (Beijing Ray Antibody Biotech) and developed using Chemiluminescent HRP Substrate (Millipore). The bands were visualised using the Fluorescence Imaging System (Tanon5200) and quantified using Image J software.

\section{Statistical analysis}

Normality and homoscedasticity assumptions were confirmed prior to the statistical analysis. All evaluated variables were subjected to an ANOVA to determine whether dietary Met levels significantly affected the observed responses $(P<0 \cdot 05)$. Differences among all treatments were separated by Duncan's multiple-range test. In addition, to determine whether the effect was linear and/or non-linear, a follow-up trend analysis using orthogonal polynomial contrasts was performed ${ }^{(45)}$ in the SPSS 22.0 (SPSS Inc.) and SAS ${ }^{\circledR}$ software packages (SAS Institute Inc.). Adjusted $R^{2}$ values (adj. $R^{2}$ ) were calculated as previously described by Kvalseth ${ }^{(46)}$. The optimum dietary Met requirement based on weight gain rate (WGR) was established through a broken-line or quadratic model ${ }^{(47,48)}$.

\section{Results}

\section{Growth performance}

The WGR of fish was significantly affected by dietary Met levels $(P<0.05)$; it increased gradually with Met of up to $1.24 \%$ and decreased gradually thereafter (Table 4). The relationship between dietary Met levels and WGR (the dependent variable) was better described by a straight broken-line or quadratic broken-line model than a linear or second-order polynomial model. The straight broken-line analysis of WGR against dietary Met levels indicated that the optimal dietary Met level for juvenile cobia growth was $1 \cdot 24 \%$ of DM (2.71\% dietary protein; Fig. 1$)$. The trends in specific growth rate (SGR) among the different experimental groups were related to those of WGR. Fish fed $1.24 \%$ dietary Met had higher values compared with fish fed other methionine levels $(P<0 \cdot 05)$. In contrast, the trends in feed conversion ratio among the different experimental groups were opposite to those of WGR. The relationship between dietary Met levels and the feed conversion ratio -dependent variable was better described by straight broken-line or quadratic broken-line models. No significant effects of dietary Met on feed intake or survival rate were observed $(P>0 \cdot 05)$.

\section{Serum hormone and glucose concentration}

The serum concentrations of IGF-I and GH were significantly affected by dietary Met levels $(P<0 \cdot 05$; Table 5$)$. The serum 
Table 4. Effects of dietary methionine (Met) levels on growth and feed utilisation of cobia for 8 weeks

\begin{tabular}{|c|c|c|c|c|c|c|c|}
\hline & Final average weight $(\mathrm{g})$ & WGR $(\%)^{*}$ & SGR $(\% / d) \dagger$ & PER $\ddagger$ & FCR§ & $\mathrm{FI} \|$ & SR (\%)ף \\
\hline \multicolumn{8}{|l|}{ Dietary Met levels (\%) } \\
\hline 0.72 & $56 \cdot 28^{\mathrm{a}}$ & $474 \cdot 74^{\mathrm{a}}$ & $3 \cdot 12^{\mathrm{a}}$ & 1.10 & $1.97^{b}$ & 1.75 & 84.76 \\
\hline 0.90 & $56 \cdot 97^{\mathrm{a}, \mathrm{b}}$ & $481 \cdot 60^{\mathrm{a}, \mathrm{b}}$ & $3 \cdot 14^{a, b}$ & $1 \cdot 21$ & $1.69^{a}$ & 1.66 & $93 \cdot 33$ \\
\hline 1.00 & $57 \cdot 64^{a, b}$ & $511 \cdot 16^{\mathrm{a}, \mathrm{b}, \mathrm{c}}$ & $3 \cdot 16^{a, b}$ & 1.25 & $1.66^{\mathrm{a}}$ & 1.63 & $92 \cdot 38$ \\
\hline 1.24 & $62 \cdot 82^{b}$ & $544 \cdot 32^{c}$ & $3 \cdot 33^{b}$ & $1 \cdot 28$ & $1.68^{\mathrm{a}}$ & 1.66 & $87 \cdot 14$ \\
\hline 1.41 & $60 \cdot 97^{a, b}$ & $514 \cdot 71^{b, c}$ & $3 \cdot 27^{a, b}$ & 1.27 & $1.69^{\mathrm{a}}$ & 1.61 & 88.57 \\
\hline 1.63 & $60 \cdot 02^{a, b}$ & $498 \cdot 45^{\mathrm{a}, \mathrm{b}, \mathrm{c}}$ & $3 \cdot 23^{a, b}$ & $1 \cdot 20$ & $1 \cdot 78^{\mathrm{a}}$ & 1.65 & 88.57 \\
\hline 1.86 & $55 \cdot 27^{a}$ & $463 \cdot 29^{a}$ & $3.09^{a}$ & 1.22 & $1 \cdot 79^{a, b}$ & 1.66 & $87 \cdot 62$ \\
\hline $\begin{array}{l}\text { Pooled standard error of treatment means }(n 3) \\
\text { ANOVA }\end{array}$ & 1.858 & $14 \cdot 874$ & 0.056 & 0.063 & 0.054 & 0.062 & 4.712 \\
\hline$P$ & 0.011 & 0.001 & 0.007 & 0.176 & 0.001 & 0.409 & 0.597 \\
\hline \multicolumn{8}{|l|}{ Regression analysis $(n 3)$} \\
\hline \multicolumn{8}{|l|}{ Linear trend } \\
\hline Adj. $R^{2}$ & -0.040 & -0.050 & -0.042 & 0.014 & -0.029 & 0.020 & 0.048 \\
\hline$P$ & 0.632 & 0.839 & 0.658 & $0 \cdot 271$ & 0.520 & 0.251 & 0.726 \\
\hline \multicolumn{8}{|l|}{ Second-order polynomial trend } \\
\hline Adj. $R^{2}$ & 0.452 & 0.582 & 0.462 & 0.249 & 0.448 & 0.131 & 0.059 \\
\hline$P$ & 0.002 & $<0.001$ & 0.001 & 0.029 & 0.002 & 0.109 & 0.632 \\
\hline \multicolumn{8}{|l|}{ Straight broken-line model } \\
\hline Adj. $R^{2}$ & 0.389 & 0.704 & 0.556 & $0 \cdot 396$ & 0.753 & $0 \cdot 268$ & 0.070 \\
\hline$P$ & 0.035 & $<0.001$ & 0.003 & 0.032 & $<0.001$ & $0 \cdot 141$ & $0 \cdot 754$ \\
\hline \multicolumn{8}{|l|}{ Quadratic broken-line trend } \\
\hline Adj. $R^{2}$ & 0.593 & 0.679 & 0.611 & 0.383 & 0.753 & 0.177 & 0.081 \\
\hline$P$ & $<0.001$ & $<0.001$ & $<0.001$ & 0.038 & $<0.001$ & 0.334 & 0.707 \\
\hline
\end{tabular}

WGR, weight gain rate; SGR, specific growth rate; PER, protein efficiency ratio; FCR, feed conversion ratio; FI, feed intake; SR, survival rate; Adj. $R^{2}$, adjusted $R^{2}$

$a, b, c$ Mean values in the same column with unlike superscript letters are significantly different $(P<0.05)$.

${ }^{*}$ WGR $(\%)=100 \times$ (final body weight - initial body weight)/initial body weight.

† SGR $(\% \mathrm{~d} / \mathrm{d})=100 \times($ In (final body weight) $-\ln$ (initial body weight) $) / \mathrm{d}$

$\ddagger \mathrm{PER}=$ wet weight gain/total protein intake.

$\S \mathrm{FCR}=$ total diet intake/total wet weight gain.

|| FI $(\% / d)=100 \times$ total diet intake (initial body weight + final body weight)/d.

If SR $(\%)=100 \times$ the final fish number/the initial fish number.

IGF-I concentration increased with the dietary Met level but only up to $1.43 \%$, after which it gradually decreased $(P<0 \cdot 05)$. The relationship between dietary Met level and the dependent variable of serum IGF-I was better described by straight broken-line model or a quadratic broken-line model. Fish fed 0.72 or $1.86 \%$ dietary Met had low GH concentrations, which were significantly lower than those in fish fed other Met levels $(P<0 \cdot 05)$. The concentrations of serum GLU in the 0.72 and $0.90 \%$ Met dietary groups were significantly lower than those in other groups $(P<0 \cdot 05)$, while no significant effect of dietary Met on INS was observed ( $P>0 \cdot 05)$.

\section{ASCT2 and $B^{0} A T 1$ gene expression in the intestinal tract,} liver and dorsal muscle

Expression of $A S C T 2$ and $B^{O} A T 1$ genes in the intestinal tract, liver and dorsal muscle were significantly influenced by the dietary Met level $(P<0 \cdot 05$; Table 6$)$. The expressions of both ASCT2 and $\mathrm{B}^{0} \mathrm{AT} 1$ in the intestinal tract of fish fed $1.24 \%$ dietary Met were significantly more up-regulated than those in fish fed other Met levels $(P<0.05)$. In the liver, fish fed 1.00 and $1.24 \%$ dietary Met had significantly higher $B^{O} A T 1$ gene expression compared with fish fed $0.72,1.63$ and $1.86 \% \operatorname{Met}(P<0.05)$. In the dorsal muscle, fish fed 1.63 and $1.86 \%$ dietary Met had significantly lower $\mathrm{B}^{0} \mathrm{AT} 1$ concentrations compared with fish fed other Met levels $(P<0 \cdot 05)$. The relationship between dietary Met level and the dependent variable of hepatic $\mathrm{B}^{0} \mathrm{AT} 1$ was best described by a quadratic broken-line model. Moreover, significant linear or second-order polynomial relationships were found between the experimental treatments and dorsal muscle $\mathrm{B}^{0} \mathrm{AT} 1$.
Insulin-like growth factor-I and target of rapamycin gene expression in the intestinal tract, liver and dorsal muscle

Gene expression of both IGF-I and TOR in the intestinal tract, liver and dorsal muscle was significantly influenced by the dietary Met level $(P<0 \cdot 05$; Table 7$)$. The transcriptional levels of IGF-I in the intestinal tracts of fish fed $0.90,1.00$ or $1.24 \%$ dietary Met were significantly lower than those in fish fed 1.41, 1.63 and $1.86 \%$ Met $(P<0.05)$. Fish fed $0.72,0.90$ or $1.00 \%$ dietary Met had significantly lower expressions of the hepatic IGF-I gene compared with other fish. In the dorsal muscle, fish fed 1.00 or $1.24 \%$ dietary Met showed significantly higher expressions of the IGF-I gene compared with other fish $(P<0 \cdot 05)$. The relationship between Met level and IGFI in both intestinal tracts and dorsal muscle was better described by a straight broken-line model or a quadratic broken-line model. Fish fed $1.00 \%$ dietary Met showed higher TOR mRNA levels in the intestinal tract compared with the 1.41, 1.63 and $1.86 \%$ groups $(P<0.05)$. Fish fed $1.24,1.41$ or $1.83 \%$ dietary Met showed significantly higher hepatic TOR gene expressions than those fed 0.90 or $1.00 \%$ Met $(P<0.05)$. In dorsal muscle, the $1.24 \%$ Met group showed the highest TOR mRNA levels, which were significantly higher compared with the other groups $(P<0 \cdot 05)$. The relationship between dietary Met and TOR in both the intestinal tract and liver was best described by straight broken-line models.

\section{Effects of target of rapamycin signalling pathway by dietary methionine}

The phosphorylation levels of TOR on $\operatorname{Ser}^{2448}$ in the dorsal muscle of fish fed $1.24 \%$ Met were significantly higher than those 

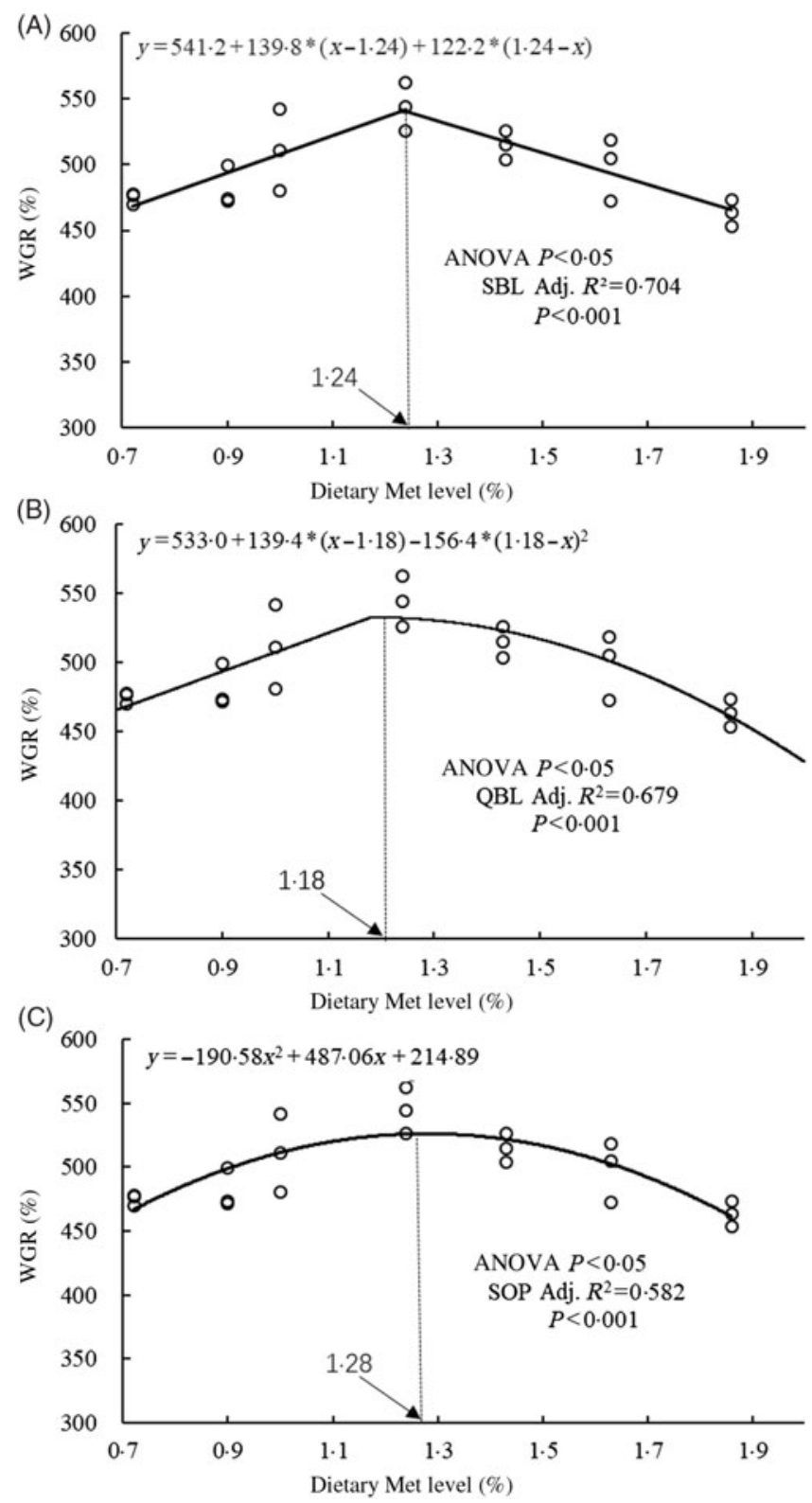

Fig. 1. Relationship between dietary methionine (Met) levels and weight gain rate (WGR) of juvenile cobia. (A) The two-slope broken-line (SBL) model would be $y=L+V^{*}(x-R)+U^{*}(R-x)$, where $(R-x)$ is defined as zero at values of $x<R$, and $(x-R)$ is defined as zero when $x>R$. (B) The quadratic broken-line (QBL) model would be $y=L+U^{*}(R-x)(R-x)+V^{*}(x-R)$, where $(R-x)$ is defined as zero at values of $x<R$, and $(x-R)$ is defined as zero when $x>R$. (C) The secondorder polynomial (SOP) model would be $y=A x^{2}+B x+C(A \neq 0, A<0)$. Adj. $R^{2}$, adjusted $R^{2}$.

of fish fed 0.72 and $1.86 \% \operatorname{Met}(P<0.05 ;$ Fig. 2$)$. The phosphorylation of S6K on Ser ${ }^{371}$ in the dorsal muscle of fish fed $1.86 \%$ Met was significantly higher than those of fish fed $0.72 \%$ Met $(P<0.05)$. The phosphorylation levels of $4 \mathrm{E}-\mathrm{BP} 1$ on $\mathrm{Thr}^{37 / 46}$ decreased with increases in Met, but there were no significant differences between treatment groups $(P>0 \cdot 05)$.

\section{Discussion}

The optimum level of Met in the diet of juvenile cobia was estimated to be $1 \cdot 24 \%(2 \cdot 71 \%, 264$ dietary protein) based on
WGR. Growth and feed utilisation increased with increases in dietary Met levels, which is consistent with previous reports on other marine fish species, such as orange-spotted grouper, Epinephelus coioides $(2.73 \% \text { dietary protein })^{(49)}$, and cobia $(2.64 \% \text { dietary protein })^{(35)}$. The growth of pigs was improved by an optimal Met level, which stimulated the up-regulation expression of AA transporters ${ }^{(50)}$. Dietary AA supplementation significantly increased the protein expression of luminal $\mathrm{B}^{0} \mathrm{AT} 1$ in the rat proximal jejunum ${ }^{(51)}$. In terms of fish species, adding AA to the diet significantly increased the mRNA expression of ASCT2 in grass carp, Ctenopharyngodon idella ${ }^{(52)}$, and significantly shifted the postprandial gene expression pattern of $\mathrm{B}^{0} \mathrm{AT} 1$ in turbot ${ }^{(20)}$. In the present experiment, the maximum mRNA levels of ASCT2 and $\mathrm{B}^{0} \mathrm{AT} 1$ in cobia intestinal tracts were found in the $1.24 \%$ Met group. Furthermore, we found a positive relationship between WGR and the gene expressions of ASCT2 $(r 0.521, P<0.05)$ and $B^{O} A T 1(r 0.623, P<0.01)$ in the intestinal tract (Table 8 ). The findings of the present study suggest that up-regulated AA transporters act as a channel that transports AA more effectively into intra-cellular spaces, thereby increasing the contents of the free AA pool and, in turn, promoting protein synthesis.

INS, GH and IGF-I play important roles in the regulation of protein metabolism ${ }^{(53)}$. Some studies have demonstrated that dietary AA influence serum or plasma INS, GH and IGF-I concentrations in fish ${ }^{(26,54)}$. In the present study, there was no significant influence between dietary Met and serum INS, which is consistent with other studies ${ }^{(53,55)}$. However, the concentration of serum GLU was significantly influenced by dietary Met level, and a lower serum GLU concentration was found in fish fed Met-deficient diets, which is similar to that previously reported in cobia ${ }^{(35)}$ and orange-spotted grouper ${ }^{(49)}$. This may be partly attributed to the long-term hypoglycaemia, leading to a lack of energy for body activity. Supplementation with adequate Met may promote gluconeogenesis and phosphoenolpyruvate carboxykinase activity and contribute to glycogen synthesis for body growth ${ }^{(56)}$. Moreover, fish fed a Met-deficient diet showed the lowest GH concentration, which corresponds with their lower growth performance. These results are in agreement with studies on the growth of farmed rabbits $^{(55)}$ and goats ${ }^{(57)}$, but contrast with a study on rainbow trout ${ }^{(58)}$ where the plasma GH levels were not affected by Met supplementation. The different results obtained by the present study may due to the diet formulations used, which were formulated under low fishmeal conditions and had seven-set Met levels.

IGF-I is the primary anabolic agent responsible for fish growth. Alteration in its serum contents and gene expression can partly account for changes in growth rate ${ }^{(54,59)}$. Previous studies report that dietary Met can influence the serum content and mRNA level of IGF-I ${ }^{(25,58)}$. In this experiment, a deficiency or excess of dietary Met decreased the concentration of serum IGF-I. This is similar to that previously reported by Zhang et al. ${ }^{(55)}$, suggesting that lower serum IGF-I due to a sub-optimal Met level may suppress the transcription of IGF-I. Katsumata et al. ${ }^{(60)}$ reported that the potential mechanisms underlying reductions in plasma IGF-I due to an imbalance of limiting AA are (1) the suppression of post-transcriptional events in IGF-I expression and (2) differences in IGF-I clearance from plasma other than suppression of IGF-I mRNA expression. In addition, circulating 
Table 5. Effects of dietary methionine (Met) levels on cobia serum glucose and hormone concentrations

\begin{tabular}{|c|c|c|c|c|}
\hline & Insulin-like growth factor-I (ng/ml) & Growth hormone (ng/ml) & Insulin $(\mu \mathrm{l} \mathrm{U} / \mathrm{ml})$ & Glucose $(\mathrm{mmol} / \mathrm{l})$ \\
\hline \multicolumn{5}{|l|}{ Dietary Met levels (\%) } \\
\hline 0.72 & $221 \cdot 63^{a}$ & $2.55^{\mathrm{a}}$ & 5.500 & $9 \cdot 24^{\mathrm{a}}$ \\
\hline 0.90 & $263.9^{a, b}$ & $2 \cdot 91^{\mathrm{b}}$ & 2.960 & $9 \cdot 22^{a}$ \\
\hline 1.00 & $373.35^{b, c, d}$ & $2 \cdot 90^{\mathrm{b}}$ & 4.000 & $10 \cdot 55^{\mathrm{b}}$ \\
\hline $1 \cdot 24$ & $392 \cdot 69^{c, d}$ & $2 \cdot 90^{\mathrm{b}}$ & 4.770 & $10 \cdot 39^{b}$ \\
\hline 1.41 & $479.67^{d}$ & $2 \cdot 97^{\mathrm{b}}$ & $6 \cdot 110$ & $10 \cdot 55^{\mathrm{b}}$ \\
\hline 1.63 & $380 \cdot 01^{\mathrm{b}, \mathrm{c}, \mathrm{d}}$ & $2 \cdot 92^{\mathrm{b}}$ & $6 \cdot 380$ & $10 \cdot 64^{\mathrm{b}}$ \\
\hline 1.86 & $279.89^{a, b, c}$ & $2.58^{\mathrm{a}}$ & 4.960 & $10 \cdot 78^{\mathrm{b}}$ \\
\hline Pooled standard error of treatment means $(n 6)$ & 54.804 & 0.137 & $1 \cdot 151$ & 0.087 \\
\hline \multicolumn{5}{|l|}{ ANOVA } \\
\hline$P$ & 0.001 & 0.010 & 0.070 & 0.001 \\
\hline \multicolumn{5}{|l|}{ Regression analysis $(n 6)$} \\
\hline \multicolumn{5}{|l|}{ Linear trend } \\
\hline Adj. $R^{2}$ & 0.071 & -0.023 & 0.037 & -0.020 \\
\hline$P$ & 0.049 & 0.783 & 0.118 & 0.420 \\
\hline \multicolumn{5}{|l|}{ Second-order polynomial trend } \\
\hline Adj. $R^{2}$ & 0.373 & 0.267 & 0.015 & 0.247 \\
\hline$P$ & $<0.001$ & 0.001 & 0.280 & 0.053 \\
\hline \multicolumn{5}{|l|}{ Straight broken-line model } \\
\hline Adj. $R^{2}$ & 0.446 & 0.259 & 0.058 & 0.036 \\
\hline$P$ & $<0.001$ & 0.009 & 0.116 & 0.448 \\
\hline \multicolumn{5}{|l|}{ Quadratic broken-line trend } \\
\hline Adj. $R^{2}$ & 0.434 & 0.276 & 0.058 & 0.289 \\
\hline$P$ & $<0.001$ & 0.008 & 0.116 & 0.176 \\
\hline
\end{tabular}

Adj. $R^{2}$, adjusted $R^{2}$.

$\mathrm{a}, \mathrm{b}, \mathrm{c}, \mathrm{d}$ Mean values in the same column with unlike superscript letters are significantly different $(P<0.05)$.

Table 6. Effects of dietary methionine (Met) levels on $A S C T 2$ and $B^{\circ} A T 1$ relative gene expression in the intestinal tract, liver and dorsal muscle of cobia

\begin{tabular}{|c|c|c|c|c|c|c|}
\hline & \multicolumn{2}{|c|}{ Intestinal tract } & \multicolumn{2}{|c|}{ Liver } & \multicolumn{2}{|c|}{ Dorsal muscle } \\
\hline & ASCT2 & $B^{\circ} A T 1$ & ASCT2 & $B^{0} A T 1$ & ASCT2 & $B^{0} A T 1$ \\
\hline \multicolumn{7}{|c|}{ Dietary Met levels (\%) } \\
\hline 0.72 & $1.00^{b, c}$ & $1.00^{\mathrm{b}}$ & $1.08^{b, c}$ & $1.02^{\mathrm{b}}$ & $1.00^{\mathrm{a}}$ & $1.00^{\mathrm{d}}$ \\
\hline 0.90 & $1 \cdot 16^{\mathrm{c}}$ & $1 \cdot 21^{b}$ & $1 \cdot 23^{c}$ & $1 \cdot 28^{b, c}$ & $1.07^{a, b}$ & $0.71^{\mathrm{b}}$ \\
\hline 1.00 & $0 \cdot 70^{\mathrm{a}, \mathrm{b}}$ & $1 \cdot 19^{b}$ & $0.70^{\mathrm{a}, \mathrm{b}, \mathrm{c}}$ & $1.57^{c}$ & $1 \cdot 34^{\mathrm{b}}$ & $0.88^{\mathrm{c}}$ \\
\hline 1.24 & $2 \cdot 03^{\mathrm{d}}$ & $3.06^{c}$ & $0.71^{a, b, c}$ & $1.49^{\mathrm{c}}$ & $1 \cdot 11^{\mathrm{a}, \mathrm{b}}$ & $0.76^{\mathrm{b}}$ \\
\hline 1.41 & $0.54^{\mathrm{a}}$ & $0.57^{a}$ & $0.94^{\mathrm{a}, \mathrm{b}, \mathrm{c}}$ & $1 \cdot 19^{b, c}$ & $1 \cdot 17^{\mathrm{a}, \mathrm{b}}$ & $0.66^{\mathrm{b}}$ \\
\hline 1.63 & $0.76^{a, b, c}$ & $0.62^{a}$ & $0.59^{a, b}$ & $0.93^{b}$ & $0.93^{\mathrm{a}}$ & $0.50^{\mathrm{a}}$ \\
\hline 1.86 & $0.53^{a}$ & $0.45^{\mathrm{a}}$ & $0.30^{\mathrm{a}}$ & $0.32^{a}$ & $0.93^{a}$ & $0.49^{\mathrm{a}}$ \\
\hline SEM & 0.048 & 0.043 & 0.058 & 0.049 & 0.04 & 0.01 \\
\hline \multicolumn{7}{|l|}{ ANOVA } \\
\hline$P$ & $<0.001$ & $<0.001$ & 0.018 & $<0.001$ & 0.048 & $<0.001$ \\
\hline \multicolumn{7}{|c|}{ Regression analysis ( $n$ 3) } \\
\hline \multicolumn{7}{|c|}{ Linear trend } \\
\hline Adj. $R^{2}$ & 0.051 & 0.043 & 0.425 & 0.320 & 0.049 & 0.744 \\
\hline$P$ & 0.173 & $0 \cdot 217$ & 0.002 & 0.006 & 0.177 & $<0.001$ \\
\hline \multicolumn{7}{|c|}{ Second-order polynomial trend } \\
\hline Adj. $R^{2}$ & 0.164 & 0.171 & 0.394 & 0.790 & 0.206 & 0.730 \\
\hline$P$ & 0.084 & 0.117 & 0.009 & $<0.001$ & 0.055 & $<0.001$ \\
\hline \multicolumn{7}{|c|}{ Straight broken-line model } \\
\hline Adj. $R^{2}$ & 0.226 & 0.336 & 0.335 & 0.768 & 0.238 & 0.138 \\
\hline$P$ & 0.237 & 0.137 & 0.082 & $<0.001$ & 0.215 & 0.305 \\
\hline \multicolumn{7}{|c|}{ Quadratic broken-line trend } \\
\hline Adj. $R^{2}$ & 0.051 & 0.256 & 0.003 & 0.811 & 0.310 & 1.212 \\
\hline$P$ & 0.335 & 0.263 & 0.803 & $<0.001$ & 0.106 & 0.571 \\
\hline
\end{tabular}

Adj. $R^{2}$, adjusted $R^{2}$.

a,b,c,d Mean values in the same column with unlike superscript letters are significantly different $(P<0.05)$.

concentrations of IGF-I have been demonstrated to be positively correlated with SGR $(r 0.573, P<0 \cdot 01)$, which is consistent with Zhang et al. ${ }^{(55)}$. Thus, the decrease in serum IGF-I levels observed in the present study probably implies a reduction in fish growth. In the present study, the lower Met level group had inhibited $I G F-I$ gene expressions in the intestinal tract, liver and dorsal muscle, which was also accompanied by lower WGR. Marked up-regulation of IGF-I transcription in the dorsal muscle of fish fed adequate Met was observed as well as higher WGR ( $r$ 0.566, $P<0 \cdot 01$; Table 8). The gene expression of $I G F-I$ was 
Table 7. Effects of dietary methionine (Met) levels on insulin-like growth factor-I (IGF-I) and target of rapamycin (TOR) relative gene expression in intestinal tract, liver and dorsal muscle of cobia

\begin{tabular}{|c|c|c|c|c|c|c|}
\hline & \multicolumn{2}{|c|}{ Intestinal tract } & \multicolumn{2}{|c|}{ Liver } & \multicolumn{2}{|c|}{ Dorsal muscle } \\
\hline & IGF-I & TOR & IGF-I & TOR & IGF-I & TOR \\
\hline \multicolumn{7}{|c|}{ Dietary Met levels (\%) } \\
\hline 0.72 & $1.00^{b, c}$ & $1.00^{b, c}$ & $1.00^{\mathrm{a}}$ & $1.02^{a, b}$ & $1.00^{\mathrm{a}}$ & $1.00^{\mathrm{a}}$ \\
\hline 0.90 & $0.47^{\mathrm{a}}$ & $1 \cdot 13^{b, c}$ & $0.83^{\mathrm{a}}$ & $0.84^{\mathrm{a}}$ & $2 \cdot 41^{\mathrm{c}}$ & $1.08^{\mathrm{a}}$ \\
\hline 1.00 & $0.55^{a, b}$ & $1.41^{\mathrm{c}}$ & $1.06^{\mathrm{a}}$ & $0 \cdot 81^{\mathrm{a}}$ & $3.36^{d}$ & $0.95^{\mathrm{a}}$ \\
\hline 1.24 & $0.52^{a, b}$ & $1.02^{b, c}$ & $2 \cdot 12^{\mathrm{b}}$ & $1 \cdot 33^{b, c}$ & $3.09^{d}$ & $1.54^{\mathrm{b}}$ \\
\hline 1.41 & $1 \cdot 19^{\mathrm{c}}$ & $0.80^{b}$ & $2 \cdot 61^{b, c}$ & $1 \cdot 29^{b, c}$ & $2 \cdot 19^{c}$ & $0.83^{\mathrm{a}}$ \\
\hline 1.63 & $1.32^{\mathrm{c}}$ & $0.58^{a, b}$ & $2 \cdot 94^{\mathrm{c}}$ & $1 \cdot 16^{\mathrm{a}, \mathrm{b}}$ & $1 \cdot 11^{\mathrm{a}}$ & $0.84^{\mathrm{a}}$ \\
\hline 1.86 & $1 \cdot 18^{\mathrm{C}}$ & $0 \cdot 11^{\mathrm{a}}$ & $2 \cdot 76^{b, c}$ & $1.61^{\mathrm{c}}$ & $1.62^{\mathrm{b}}$ & $0.65^{\mathrm{a}}$ \\
\hline \multicolumn{7}{|l|}{ ANOVA } \\
\hline$P$ & 0.005 & 0.004 & $<0.001$ & 0.003 & $<0.001$ & 0.020 \\
\hline \multicolumn{7}{|c|}{ Regression analysis ( $n$ 3) } \\
\hline \multicolumn{7}{|c|}{ Linear trend } \\
\hline Adj. $R^{2}$ & 0.268 & 0.482 & 0.791 & 0.449 & -0.042 & 0.132 \\
\hline$P$ & 0.013 & $<0.001$ & $<0.001$ & 0.001 & 0.583 & 0.077 \\
\hline \multicolumn{7}{|c|}{ Second-order polynomial trend } \\
\hline Adj. $R^{2}$ & 0.286 & 0.617 & 0.790 & 0.433 & 0.422 & 0.257 \\
\hline$P$ & 0.026 & $<0.001$ & $<0.001$ & 0.004 & 0.006 & 0.042 \\
\hline \multicolumn{7}{|c|}{ Straight broken-line model } \\
\hline Adj. $R^{2}$ & 0.018 & 0.690 & 0.720 & 0.633 & 0.690 & 0.328 \\
\hline$P$ & 0.288 & $<0.001$ & $<0.001$ & $<0.001$ & $<0.001$ & 0.124 \\
\hline \multicolumn{7}{|c|}{ Quadratic broken-line trend } \\
\hline Adj. $R^{2}$ & 0.313 & 0.668 & 0.747 & 0.633 & 0.584 & 0.341 \\
\hline$P$ & 0.050 & $<0.001$ & $<0.001$ & $<0.001$ & 0.005 & 0.110 \\
\hline
\end{tabular}

Adj. $R^{2}$, adjusted $R^{2}$.

a,b,c,d Mean values in the same column with unlike superscript letters are significantly different $(P<0.05)$.

(A)

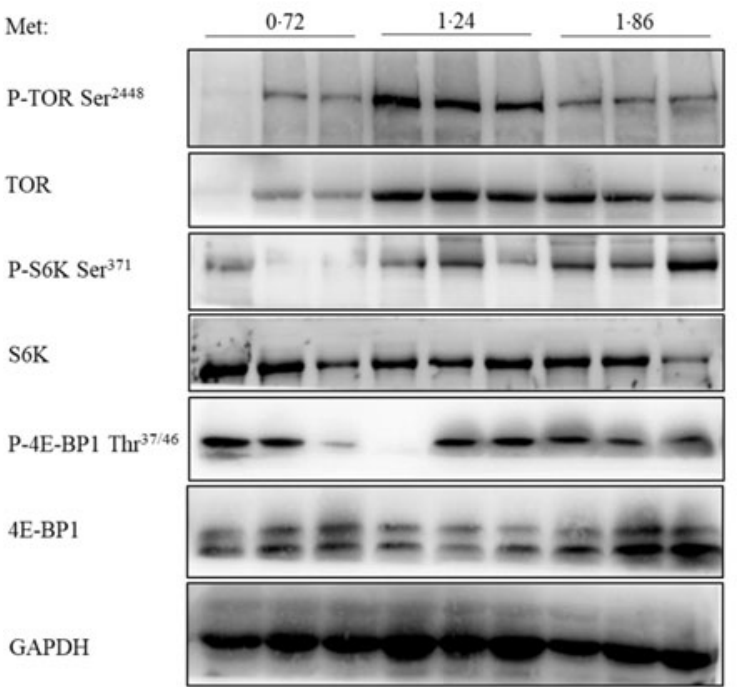

(B)

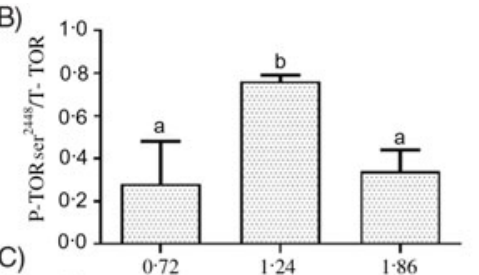

(C)

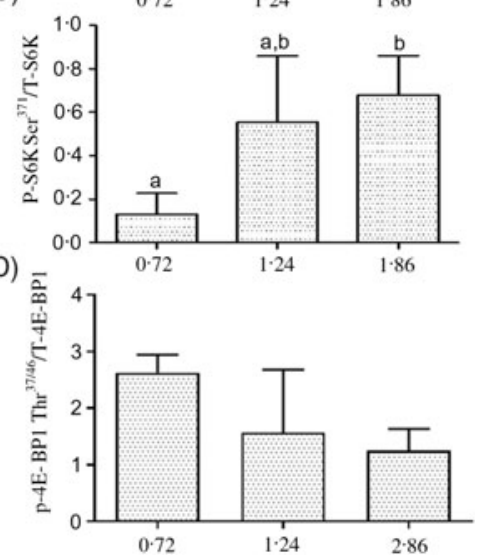

Fig. 2. Total and phosphorylation levels of target of rapamycin (TOR), S6 kinase (S6K) and 4E-binding protein 1 (4E-BP1) were examined by Western blot (A) and quantified (B-D) in the dorsal muscle of cobia fed the $0.72,1.24$, and $1.86 \%$ methionine (Met) diets. Results are represented as means with standard errors $(n 3)$ and were analysed using ANOVA followed by Duncan's multiple range test. ${ }^{a, b}$ Mean values with unlike letters are significantly different $(P<0.05)$. GAPDH, glyceraldehyde-3-phosphate dehydrogenase.

suppressed by a Met-deficient diet, as confirmed by previous studies on Atlantic salmon, Salmo salar(61), rainbow trout ${ }^{(25)}$ and juvenile cobia ${ }^{(36)}$, and was up-regulated with increases in Met, suggesting that, at the transcriptional level, IGF-I is triggered by dietary Met content in fish. We also found that changes in IGFI expression were positively related to the mRNA levels of ASCT2 in the dorsal muscle of fish $(r 0 \cdot 652, P<0 \cdot 01$; Table 8$)$. IGF-I can increase the placental mRNA expression of the neutral AA 
Table 8. Correlation analysis of parameters in intestinal tract, liver dorsal muscle of cobia

\begin{tabular}{|c|c|c|c|c|c|c|c|}
\hline \multirow[b]{2}{*}{ Independent parameters } & \multirow[b]{2}{*}{ Dependent parameters } & \multicolumn{2}{|l|}{ Intestinal tract } & \multicolumn{2}{|l|}{ Liver } & \multicolumn{2}{|l|}{ Dorsal muscle } \\
\hline & & Correlation coefficient & $P$ & Correlation coefficient & $P$ & Correlation coefficient & $P$ \\
\hline \multirow[t]{4}{*}{ Weight gain rate } & ASCT2 & $0.521^{*}$ & 0.015 & 0.058 & 0.802 & $0.455^{\star}$ & 0.038 \\
\hline & $\mathrm{B}^{0} \mathrm{AT} 1$ & $0.623^{\star \star}$ & 0.003 & $0.551^{* *}$ & 0.010 & 0.058 & 0.803 \\
\hline & IGF-I & -0.195 & 0.396 & $0 \cdot 124$ & 0.591 & $0.566^{\star \star}$ & 0.007 \\
\hline & TOR & 0.388 & 0.082 & -0.006 & 0.981 & $0.526^{\star}$ & 0.014 \\
\hline \multirow[t]{4}{*}{ Specific growth rate } & ASCT2 & 0.425 & 0.055 & 0.084 & 0.716 & 0.354 & 0.116 \\
\hline & $\mathrm{B}^{0} \mathrm{AT} 1$ & $0.508^{\star}$ & 0.019 & 0.352 & 0.117 & -0.078 & 0.736 \\
\hline & IGF-I & -0.047 & 0.841 & 0.288 & 0.206 & 0.337 & 0.135 \\
\hline & TOR & $0 \cdot 190$ & 0.409 & 0.129 & 0.578 & $0.472^{*}$ & 0.031 \\
\hline \multirow[t]{3}{*}{ ASCT2 } & $\mathrm{B}^{0} \mathrm{AT} 1$ & $0.912^{\star \star}$ & $<0.001$ & 0.307 & 0.176 & 0.373 & 0.096 \\
\hline & IGF-I & $-0.437^{\star}$ & 0.048 & $-0.545^{\star}$ & 0.011 & $0.652^{* *}$ & 0.001 \\
\hline & TOR & 0.353 & 0.116 & $-0.563^{\star *}$ & 0.008 & 0.236 & 0.302 \\
\hline \multirow[t]{2}{*}{$\mathrm{B}^{0} \mathrm{AT} 1$} & IGF-I & $-0.585^{\star \star}$ & 0.005 & $-0.469^{\star}$ & 0.032 & 0.250 & 0.274 \\
\hline & TOR & 0.364 & 0.105 & $-0.540^{\star}$ & 0.012 & 0.427 & 0.053 \\
\hline IGF-I & TOR & $-0.554^{\star *}$ & 0.009 & $0.675^{\star \star}$ & 0.001 & $0.518^{*}$ & 0.016 \\
\hline
\end{tabular}

IGF-I, insulin-like growth factor-I; TOR, target of rapamycin.

Significant correlations: * $P<0.05,{ }^{* *} P<0.01$.

transporter ATA2 $\left(\right.$ SlC38A2) ${ }^{(62)}$. These results indicate that Met-stimulated IGF-I may regulate ASCT2 in the dorsal muscle at the transcription level, while the relationship between them needs further research. Moreover, IGF-I bound with its receptor in the cell membrane can activate the TOR protein via the PI3K-Akt pathway ${ }^{(63)}$.

The TOR pathway responds not only to dietary AA but also to growth factors such as INS and IGF and then regulates cell growth $^{(27)}$. IGF-I promotes protein synthesis through mammalian TOR (mTOR) in differentiating oligodendrocytes ${ }^{(64)}$. Similar results were also observed in the present study: there was a positive relationship between the mRNA levels of TOR and $I G F-I$ genes in the liver $(r 0 \cdot 675, P<0 \cdot 01)$ and dorsal muscle ( $r 0 \cdot 518, P<0 \cdot 05$; Table 8 ), implying that IGF-I mRNA may participate in protein turnover by the TOR gene, which is centrally involved in growth regulation. In addition, the mRNA level of TOR and phosphorylation level of TOR on $\mathrm{Ser}^{2448}$ in the dorsal muscle of fish fed $1.24 \%$ Met were significantly higher than those fed other Met levels. These results are consistent with previous findings on rainbow trout ${ }^{(31)}$ and turbot ${ }^{(32)}$, showing that the mRNA and phosphorylation level of TOR was up-regulated by the optimum Met concentration. The phosphorylation of S6K on $\operatorname{Ser}^{371}$ in the dorsal muscle of fish fed $0.72 \%$ Met was significantly lower than that in fish fed $1.86 \%$ Met, while we failed to detect any significant change in the phosphorylation of 4E-BP1, which is similar to a previous report on rainbow trout ${ }^{(31)}$. Such a discrepancy between the phosphorylation levels of these two proteins ( 56 and 4E-BP1) has already been observed in the liver of rats in response to dietary Met intake ${ }^{(65)}$ and highlights the complexity of the signalling network involved in the regulation of the activation of these translation initiation factors. These results suggest that the capacity for regulating protein synthesis according to dietary Met level might be mediated by the TOR/ S6K signalling pathway via IGF-I. On the other hand, a potential relationship between hepatic TOR and AA transporters (ASCT2 and $\mathrm{B}^{0} \mathrm{AT} 1$ ) was observed in the present study, supporting the hypothesis that Met-regulated TOR signalling might be sensed by these genes. Previous reports indicate that PI3K/Akt/mTOR signalling pathways play a critical role in modulating ASCT2 expression in porcine jejunal epithelial cell line IPEC-J2 $2^{(24)}$, ASCT2 silencing by the inducible antisense RNA system leads to suppression of mTOR signalling to $\mathrm{p} 70-\mathrm{S} 6 \mathrm{~K}$ and $4 \mathrm{E}-\mathrm{BP} 1^{(18)}$. These results collectively establish a reciprocal regulatory connection between TOR and ASCT2. However, the reasons for the correlation between TOR and AA transporters at protein level in fish remain unclear, and further study of the activity of the proteins in this cascade is needed.

\section{Conclusions}

The straight broken-line analysis of WGR against dietary Met level indicates that juvenile cobia get the better growth at dietary Met $1.24 \%$ (of DM), corresponding to $2.71 \%$ dietary protein. Optimal Met supplementation in a low-fishmeal diet increased cobia growth through a mechanism that could be partly attributed to Met's ability to affect the TOR/S6K signalling pathway by enhancing ASCT2 and IGF-I transcription in cobia dorsal muscle. Our results also suggested that Met-stimulated IGF-I may also regulate ASCT2 expression in cobia dorsal muscle, while the relationship between them needs further research. Sub-optimal Met-induced TOR signalling in cobia liver may negatively feedback regulate AA transporters at the transcription level.

\section{Acknowledgements}

We wish to extend our sincere appreciation to Yong Guo and Zipei Su for their assistance in the experiment.

This research was supported by the Natural Science Foundation of China (grant number 31402310) and the China Agriculture Research System (grant number CARS-47).

The authors' contributions are as follows: S. C. and B. T. designed the study. X. D. and S. Z. purchased the feed ingredients and analytical reagents, respectively. Y. H. carried out the animal feeding trial and sample collection. H. L. and Q. Y. participated in the interpretation of the results. F. H. and D. L. 
contributed to the sample collection and data analyses. Y. H. wrote the manuscript; S. C. had primary responsibility for the final content of the manuscript. All authors read and approved the final version of the manuscript.

The authors declare that there are no conflicts of interest.

\section{Ethical approval}

All applicable international, national, and/or institutional guidelines for the care and use of animals were followed. All procedures performed in the present study involving animals were done so in accordance with the ethical standards of the institution at which the present study was conducted.

\section{Supplementary material}

For supplementary material referred to in this article, please visit https://doi.org/10.1017/S0007114519001648

\section{References}

1. Nwanna LC, Lemme A, Metwally A, et al. (2012) Response of common carp (Cyprinus carpio L.) to supplemental DL-methionine and different feeding strategies. Aquaculture 356, 365-370.

2. Green K (2016) Fishmeal and fish oil facts and figures. Seafish 12, 1-33.

3. National Research Council (NRC) (2011) Nutrient Requirements of Fish and Shrimp. Washington, DC: The National Academies Press.

4. Kwasek K, Terova G, Lee BJ, et al. (2014) Dietary methionine supplementation alters the expression of genes involved in methionine metabolism in salmonids. Aquaculture 433, 223-228.

5. Figueiredo-Silva C, Lemme A, Sangsue D, et al. (2015) Effect of DL-methionine supplementation on the success of almost total replacement of fish meal with soybean meal in diets for hybrid tilapia (Oreochromis niloticus $\times$ Oreochromis mossambicus). Aquacult Nutr 21, 234-241.

6. Saravanan S, Geurden I, Figueiredosilva AC, et al. (2013) Oxygen consumption constrains food intake in fish fed diets varying in essential amino acid composition. PLOS ONE $\mathbf{8}$, e72757.

7. Tulli F, Messina M, Calligaris M, et al. (2010) Response of European sea bass (Dicentrarchus labrax) to graded levels of methionine (total sulfur amino acids) in soya protein-based semi-purified diets. Br J Nutr 104, 664-673.

8. Bröer S (2008) Amino acid transport across mammalian intestinal and renal epithelia. Physiol Rev 88, 249-286.

9. Taylor PM (2014) Role of amino acid transporters in amino acid sensing. Am J Clin Nutr 99, 223-230.

10. Segovia-Quintero MA \& Reigh RC (2004) Coating crystalline methionine with tripalmitin-polyvinyl alcohol slows its absorption in the intestine of Nile tilapia, Oreochromis niloticus. Aquaculture 238, 355-367.

11. Bakke AM, Tashiian DH, Wang CF, et al. (2010) Competition between selenomethionine and methionine absorption in the intestinal tract of green sturgeon (Acipenser medirostris). Aquat Toxicol 96, 62-69.

12. Cozzi S, Lorenzo A, Gómez T, et al. (1993) Intestinal L-methionine transport in the cultured gilthead bream (Sparus aurata). J Comp Physiol A 106, 609-615.
13. Chen J, Zhu Y \& Hu M (1994) Mechanisms and kinetics of uptake and efflux of L-methionine in an intestinal epithelial model (Caco-2). J Nutr 124, 1907-1916.

14. Soriano-García JF, Torras-Llort M, Ferrer R, et al. (1998) Multiple pathways for L-methionine transport in brush-border membrane vesicles from chicken jejunum. J Physiol 509, 527-539.

15. Duka A \& Ahearn GA (2013) L-Leucine, L-methionine, and L-phenylalanine share a $\mathrm{Na}^{+} / \mathrm{K}^{+}$-dependent amino acid transporter in shrimp hepatopancreas. J Comp Physiol B 83, 763-771.

16. Huang Q, Li N, Zhang W, et al. (2008) $\mathrm{Na}^{+}$-dependent neutral amino acid transporter ASCT2 is downregulated in seriously traumatized human intestinal epithelial cells. $J$ Pediatr Gastroenterol Nutr 46, 71-79.

17. Ochiai H, Onda K, Ogihara K, et al. (2012) cDNA sequence and tissue distribution of canine Na-dependent neutral amino acid transporter 2 (ASCT 2). J Vet Med Sci 74, 1505-1510.

18. Fuchs BC \& Bode BP (2005) Amino acid transporters ASCT2 and LAT1 in cancer: partners in crime? Semin Cancer Biol 15, 254-266.

19. Bröer A, Klingel K, Kowalczuk S, et al. (2004) Molecular cloning of mouse amino acid transport system $\mathrm{B}^{0}$, a neutral amino acid transporter related to Hartnup disorder. J Biol Chem 279, 24467-24476.

20. Xu DD, He G, Mai KS, et al. (2016) Postprandial nutrient-sensing and metabolic responses after partial dietary fishmeal replacement by soyabean meal in turbot (Scophthalmus maximus L.). BrJ Nutr 115, 379-388.

21. Song F, Xu D, Zhou H, et al. (2017) The differences in postprandial free amino acid concentrations and the gene expression of PepT1 and amino acid transporters after fishmeal partial replacement by meat and bone meal in juvenile turbot (Scophthalmus maximus L.). Aquacult Res 48, 3766-3781.

22. Goberdhan DC, Meredith D, Boyd CA, et al. (2005) PAT-related amino acid transporters regulate growth via a novel mechanism that does not require bulk transport of amino acids. Development 132, 2365-2375.

23. Hyde R, Cwiklinski E, MacAulay K, et al. (2007) Distinct sensor pathways in the hierarchical control of SNAT2, a putative amino acid transceptor, by amino acid availability. J Biol Chem 282, 19788-19798.

24. Zhang S, Ren M, Zeng X, et al. (2014) Leucine stimulates ASCT2 amino acid transporter expression in porcine jejunal epithelial cell line (IPEC-J2) through PI3K/Akt/mTOR and ERK signaling pathways. Amino Acids 46, 2633-2642.

25. Rolland M, Dalsgaard J, Holm J, et al. (2015) Dietary methionine level affects growth performance and hepatic gene expression of GH-IGF system and protein turnover regulators in rainbow trout (Oncorbynchus mykiss) fed plant protein-based diets. Comp Biochem Phys B 181, 33-41.

26. Gaylord TG, Barrows FT, Teague AM, et al. (2007) Supplementation of taurine and methionine to all-plant protein diets for rainbow trout (Oncorbynchus mykiss). Aquaculture 269, 514-524.

27. Wullschleger S, Loewith R \& Hall MN (2006) TOR signaling in growth and metabolism. Cell 124, 471-484.

28. Flora RPD, Dionello NJL, Benitez L, et al. (2017) IGF-I and GHR gene expression in liver and breast muscle of meat quails supplemented with different levels of methionine in two successive generations. Arq Bras Med Vet Zootec 69, 205-213

29. Stubbs AK, Wheelhouse NM, Lomax MA, et al. (2002) Nutrienthormone interaction in the ovine liver: methionine supply selectively modulates growth hormone-induced IGF-I gene expression. J Endocrinol 174, 335-341. 
30. Liu Y, Ke Z, Dan W, et al. (2017) Dynamic feeding low and high methionine diets affect the diurnal rhythm of amino acid transporters and clock related genes in jejunum of laying hens. Biol Rhythm Res 49, 1-9.

31. Belghit I, Skibacassy S, Geurden I, et al. (2014) Dietary methionine availability affects the main factors involved in muscle protein turnover in rainbow trout (Oncorbynchus mykiss). BrJ Nutr 112, 493-503.

32. Jiang HW, Bian FY, Zhou HH, et al. (2017) Nutrient sensing and metabolic changes after methionine deprivation in primary muscle cells of turbot (Scophthalmus maximus L.). J Nutr Biochem 50, 74-82.

33. Tien NV, Chinh DTM, Huong TTM, et al. (2016) Development of a nutritional model to define the energy and protein requirements of cobia, Rachycentron canadum. Aquaculture $\mathbf{4 6 3}$, 193-200.

34. Dippold DA, Leaf RT, Franks JS, et al. (2017) Growth, mortality, and movement of cobia (Rachycentron canadum). Fish $B-N O A A$ 115, 460-472.

35. Zhou Q, Wu Z, Tan B, et al. (2006) Optimal dietary methionine requirement for juvenile cobia (Rachycentron canadum). Aquaculture 258, 551-557.

36. Wang Z, Mai KS, Xu W, et al. (2016) Dietary methionine level influences growth and lipid metabolism via GCN2 pathway in cobia (Rachycentron canadum). Aquaculture $\mathbf{4 5 4}$ $148-156$.

37. Tadashi A (2007) Amino acids are more important insulinotropins than glucose in a teleost fish, barfin flounder (Verasper moseri). Gen Comp Endocrinol 151, 308-317.

38. Shepherd BS, Drennon K, Johnson J, et al. (2005) Salinity acclimation affects the somatotropic axis in rainbow trout. Am J Physiol Regul Integr Comp Physiol 288, R1385-R1395.

39. Baños N, Planas JV, Gutiérrez J, et al. (1999) Regulation of plasma insulin-like growth factor-I levels in brown trout (Salmo trutta). Comp Biochem Physiol 124, 33-40.

40. Luo YW, Ai QH, Mai KS, et al. (2013) Effects of dietary corn gluten meal on growth performance and protein metabolism in relation to IGF-I and TOR gene expression of juvenile cobia (Rachycentron canadum). J Ocean Univ China 12, 418-426.

41. Yao CL, Kong P, Wang ZY, et al. (2009) Molecular cloning and expression of MyD88 in large yellow croaker, Pseudosciaena crocea. Fish Shellfish Immunol 26, 249-255.

42. Wang QC, He G, Mai KS, et al. (2016) Chronic rapamycin treatment on the nutrient utilization and metabolism of juvenile turbot (Psetta maxima). Sci Rep 6, 28068.

43. Dai W, Panserat S, Mennigen JA, et al. (2013) Post-prandial regulation of hepatic glucokinase and lipogenesis requires the activation of TORC1 signaling in rainbow trout (Oncorhynchus mykiss). J Exp Biol 216, 4483-4492.

44. Tian J, Wang K, Wang X, et al. (2018) Soybean saponin modulates nutrient sensing pathways and metabolism in zebrafish. Gen Comp Endocrinol 257, 246-254.

45. Davis MJ (2010) Contrast coding in multiple regression analysis: strengths, weaknesses, and utility of popular coding structures. J Data Sci 8, 61-73.

46. Kvålseth TO (1985) Cautionary note about R2. Am Stat 39, 279-285.

47. Li X, Wu X, Dong Y, et al. (2019) Effects of dietary lysine levels on growth, feed utilization and related gene expression of juvenile hybrid grouper (Epinephelus fuscoguttatus $9 \times$ Epinephelus lanceolatus ơ). Aquaculture 502, 153-161.

48. Robbins KR, Saxton AM \& Southern LL (2006) Estimation of nutrient requirements using broken-line regression analysis. J Anim Sci 84, E155-E165.
49. Luo Z, Liu YJ, Mai KS, et al. (2005) Dietary L-methionine requirement of juvenile grouper Epinephelus coioides at a constant dietary cystine level. Aquaculture 249, 409-418.

50. García-Villalobos $\mathrm{H}$, Morales-Trejo A, Araiza-Piña BA, et al. (2012) Effects of dietary protein and amino acid levels on the expression of selected cationic amino acid transporters and serum amino acid concentration in growing pigs. Arch Anim Nutr 66, 257-270.

51. Jando J, Camargo S, Herzog B, et al. (2017) Expression and regulation of the neutral amino acid transporter B0AT1 in rat small intestine. PLOS ONE 12, e0184845.

52. Hu R, Wang Y, Qu F, et al. (2016) Molecular characterization and dietary regulation of the AlaSerCys transporter 2 in grass carp, Ctenopharyngodon idella. J World Aquacult Soc $\mathbf{4 8}$, 333-341.

53. Li C \& Zhao G (2011) Relationships between methionine supply, nitrogen retention and plasma insulin-like growth factor-I in growing sheep nourished by total intragastric infusions. Asian-Australas J Anim Sci 24, 1393-1398.

54. Han F, Chi S, Tan B, et al. (2018) Metabolic and immune effects of orange-spotted grouper, Epinephelus coioides induced by dietary arginine. Aquacult Rep 10, 8-16.

55. Zhang YC \& Li FC (2010) Effect of dietary methionine on growth performance and insulin-like growth factor-I mRNA expression of growing meat rabbits. J Anim Physiol Anim Nutr 94, 803-809.

56. Chi SY, Wang XW, Tan BP, et al. (2015) Effects of dietary methionine on growth performance, anti-oxidation and gluconeogenesis-related enzyme activities of juvenile grouper, Epinephelus coioides. Acta Hydrobiol Sin 39, 645-652 (in Chinese with English abstract).

57. Sun ZH, Tan ZL, Yao JH, et al. (2007) Effects of intra-duodenal infusion of limiting amino acids on plasma insulin-like growth factor I, growth hormone, insulin and liver insulin-like growth factor I mRNA in growing goat fed a maize stover-based diet. Asian Austral J Anim 20, 733-741.

58. Delbertmiii G, Frederict B, Paul B, et al. (2007) Expanding the utilization of sustainable plant products in aquafeeds: a review. Aquacult Res 38, 551-579.

59. Wu M, Wu X, Lu S, et al. (2018) Dietary arginine affects growth, gut morphology, oxidation resistance and immunity of hybrid grouper (Epinephelus fuscoguttatus $\$ \times$ Epinephelus lanceolatus ${ }^{*}$ ) juveniles. Br J Nutr 120, 269-282.

60. Katsumata M, Kawakami S, Kaji Y, et al. (2002) Differential regulation of porcine hepatic IGF-I mRNA expression and plasma IGF-I concentration by a low lysine diet. J Nutr 132, 688-692.

61. Hevrøy EM, Elmowafi A, Taylor RG, et al. (2007) Lysine intake affects gene expression of anabolic hormones in Atlantic salmon, Salmo salar. Gen Comp Endocrinol 152, 39-46.

62. Sferruzziperri AN, Owens JA, Standen P, et al. (2007) Early pregnancy maternal endocrine insulin-like growth factor I programs the placenta for increased functional capacity throughout gestation. Endocrinology 148, 4362-4370.

63. Chen J, Alberts I \& Li X (2014) Dysregulation of the IGF-I/PI3K/ AKT/mTOR signaling pathway in autism spectrum disorders. Int J Dev Neurosci 35, 35-41.

64. Bibollet-Bahena O \& Almazan G (2009) IGF-1-stimulated protein synthesis in oligodendrocyte progenitors requires $\mathrm{PI} 3 \mathrm{~K} / \mathrm{mTOR} /$ Akt and MEK/ERK pathways. J Neurochem 109, $1440-1451$

65. Sikalidis AK, Mazor KM, Kang M, et al. (2013) Total 4EBP1 is elevated in liver of rats in response to low sulfur amino acid intake. J Amino Acids 2013, 864757. 